Peer Reviewed Article

ISSN: 2162-3104 Print/ ISSN: 2166-3750 Online Volume 7, Issue 4 (2017), pp. 1104-1112

(C) Journal of International Students

http://jistudents.org/

doi: $10.5281 /$ zenodo. 1035973

\title{
Ivy League Experience: Increasing Care, Increasing Engagement
}

\author{
Silvester G. Mata Jr. \\ University of Houston, USA
}

\begin{abstract}
The purpose of this personal narrative is to document initiatives that were designed and implemented to increase engagement and inclusivity for international students. The university campus of focus is a historically elite institution that enrolls one out of five international undergraduate students when compared to domestic peers. Initiatives focused on welcome events (i.e., orientation, campus tours, student panels) were implemented along with initiatives focused on student mental health and student wellness. Successful initiatives utilized campus resources such as university crisis and alert teams in addition to campus resources focused on counseling and student health.
\end{abstract}

Keywords: Codeswitching, Crisis team, Elite institution, Engagement

In recent years, there has been an increase of international students choosing to study at higher education institutions (HEI) within the United States. Recently, the Institute of International Education (2015) reported that a total of 974,926 international students studied in the United States during 2014-2015. Though this equates to approximately $8 \%$ of total fulltime students enrolled in 2015 (National Center for Education Statistics, 2016), international students have become a growing population on college campuses. 
Specifically, at Cornell University, a prestigious Ivy League institution, one out of every five undergraduate students is an international student (Cornell University International Students \& Scholars Office, 2016). Not only are international students the largest demographic population in their 2016 cohort, but since 2006, it has been one of the fastest growing populations at Cornell (Cornell University International Students \& Scholars Office, 2016). It is estimated that within four years, the international undergraduate population will grow to a steady $25 \%$ at Cornell University. But are the services and programming created for international students equal to the services that domestic students receive? And if so, what is the foundation that these services are based upon?

This practitioner narrative will discuss initiatives and strategies that were implemented at Cornell University to assist in helping the transition and success of its growing international student population. This narrative will include a brief overview of student development theories and literature that were considered in the development of student improvement initiatives. Following the overview, this narrative will examine specific initiatives that were created to improve the student experience of international students. Finally, a conclusion will discuss the challenges, limitations, and implications for future research.

\section{LITERATURE REVIEW}

Although they may be strangers to the campus, and possibly to the United States, international students seek services and programming that is equal to that of their domestic peers. Opportunities for engagement are extremely important as scholars predict it is the cornerstone that will increase opportunities for academic success (Kuh, 2009). It is imperative that university staff understand how scholarship and research can impact the creation process of initiatives. This understanding can possibly lead to engagement opportunities for creating a sense of belonging, which may generate greater academic success for students. In recent years, concepts of diversity have become the cornerstone and foundation for increasing services for students (Hurtado, 2007). However, programming focused on the diversity of undergraduate students often do not include the international student population because their formal designation as international students often puts them in a unique category within university systems which may often restrict them to offices focused only on International Students (Cornell University Office of the Registrar, 2017). While methods and concepts 
focused on increasing diversity has shown that they do indeed work, to be even more effective, initiatives focused on international students must be properly adapted (Nagda, Gurin, Sorensen, \& Zúñiga, 2009).

Seminars, workshops and other activities with outcomes to increase building community allow international students to feel a part of the campus and university community. Feeling inclusive of community activities allows international students to see that they matter in the eyes of university staff and other university students (Patton, Guido, Quaye, Forney \& Evans, 2016; Schlossberg, 1989). Additionally, when students feel that they matter, the probability of feeling marginalized is reduced (Patton et al., 2016; Schlossberg, 1989). Schlossberg's (1989) theory of mattering and marginality has been used in the development of domestic students. It can also be applied to international students if university staff takes into consideration the holistic view of the student and the various identities that resonate within international student communities (Patton et al., 2016). Taking into consideration the totality of a student's identity allows university staff to employ resources and tactics for students to find their inner voice while also taking into consideration views from within the campus community and outside the community (Torres, Jones, \& Renn, 2009).

In recent years, another great resource for international students has been teams of university staff and faculty called crisis teams. Crisis teams were shown to be highly influential to Texas A\&M University following the fall of a 30-foot bonfire. The annual bonfire which occurs before Texas A\&M's Maroon Out game in 1999 ended in tragedy when the bonfire collapsed and killed 12 current students and one alumnus (Gortner \& Pennebaker, 2003). The Texas A\&M Crisis team was influential in assisting community, parents, and students to connect with campus and local resources. Additionally, they provided information and served as liaisons to mental health officials to assist in grieving. The notion of a crisis team also showed relevance when in 2007 a lone gunman killed 33 individuals (including himself) on the campus of Virginia Tech University (Wigley \& Fontenot, 2010).

\section{PRACTICES AND INITIATIVES}

In my former professional role, it was my responsibility to draft and implement initiatives to increase a student's sense of belonging. This was part of a university campaign, which required the participation of all 
colleges, academic units, and staff departments (Cornell University, 2017). However, because the campaign was centered on the concept of diversity, many felt that international students were not an appropriate audience on whom we should focus. In my college, when the word diversity is mentioned, it was solely focused on domestic racial constructs (Parekh, 2000). Because of this reason the idea of including international students in diversity initiatives was less receptive than expected. However, it was my belief that the large number of international students within my college (Cornell University International Students \& Scholars Office, 2016) and the overall diversity found within the international student population necessitated that they were included in my initiatives.

Though there existed many different programming opportunities (e.g., college orientation, student financial aid workshops, residence hall tours) for our growing international student population, I felt they needed something different and unique. To accomplish this, I began the work of creating a new initiative focused on international students' mental health. Due to a variety of concepts and stereotypes such as model minority, stereotypes, in addition to cultural differences, many international students' mental health issues are ignored (Hunt \& Eisenberg, 2010). To create a foundation for new initiatives, I needed to reach beyond my college to create a network of support. Cornell University hosts several cultural centers dedicated to various cultures and demographics. Research has shown that cultural centers have been an influential piece in creating a more inclusive environment in addition to providing support as it relates to customs, culture and overall campus experience (Ladson-Billings, 2012). However, I did not want to create a support system that perpetuated notions of isolation, ethnocentric thinking, or potentially increased opportunity for students to alienate themselves from other students.

To challenges these notions, I hosted panels consisting of students and staff from campus cultural centers. Inviting students that represented a variety of cultural centers was to highlight how students may invest in their university community by highlighting and showcasing their culture. The benefit of including students (specifically upperclassmen) highlighted the accomplishment of surviving at the university while maintaining a connection to cultural artifacts, identity, and customs. This helped incoming students understand that their academic success did not mean that they must disavow and destroy connections to their cultural background and history. For many students, their connection to their culture allows for support, belief, and faith in challenging times. Within many of the seven colleges at 
Cornell University, students will look toward staff and faculty that may share or have direct connections to their cultural background. However, to increase a student's cultural and professional capital, associating with individuals who reside outside of their cultural community, who support them while at the same time recognizing their culture and differences may better prepare students for the world and life outside the college and university setting.

An additional initiative that was launched was the selection of a staff member who would serve as the college crisis manager. As the college crisis manager, I served on university wide committees such as the Bias Assessment Response Team, Crisis Managers, and the University Alert Team. The insertion of a crisis manager within the college allowed us to understand several advantages of having this role embedded in the college. The first advantage was revealed in reviewing survey data from current international students gathered during First-Year Parents Weekend. As international parents would visit and interact with college administration and admission officers, they would voice their concern of leaving their child and the distance that was between them. They would ask questions such as, "What would happen if my child would get sick? What would happen if I can't reach my child for several days? What would happen if my child goes off his medication and has a severe reaction?" Their worries were lessened by knowing that through a system of protocols, their worries would be relayed to somebody properly trained to deal with such circumstances in a proper, professional, and caring manner. Parents were relieved that an incollege crisis manager was available throughout the day, over summer break, and had the support of the university police department and community medical resources.

Students were relieved in knowing that there was somebody within the college that actually cared about their mental health and wellbeing. Because of the increasing numbers of international students, many students believe that they may get lost in the system and be forgotten. By coupling a crisis manager with a safe space location, students found the courage to talk about issues such as mental health, depression, abuse, or academic needs (e.g., grades, semester leave of absence, possible failure of a course) that may have otherwise been seen as possible topics of shame or possibly disrespect within their families. However, for some students, concepts such as mental health, wellness, depression, and mental fatigue still presented a challenge due to the stigma of them being topics that re often seen as taboo within their respective cultures. 
To compensate for possible cultural stigmas with mental health, workshops were done in tandem with both crisis managers and mental health practitioners. The purpose of presenting the workshop in pairs was to translate mental health resources, services, and concepts into a framework that would serve the students. For example, we used code switching to relay information to students. Code switching is often used by underrepresented students when they switch communication techniques and standards (Chauncey, Grainger, \& Holcomb, 2008). Often used in the classroom, students will learn various concepts and then, upon returning to their original community, will translate what they have learned in a way that their family or community will understand (Lin, 2013; Milroy \& Muysken, 1995). However, in this situation, code switching techniques were used to translate how mental health services could support individual academic pursuits.

Instead of using medical terms to describe processes and possible diagnoses, the crisis manager and the mental health technician were able to express benefits and services in terms that an international student would understand. To strengthen this technique, instead of focusing on language related to university goals or that speak only towards goals of the health center, conversations would also focus on the goals of the students. Because many first-year students are looking for tools to assist them in their goal of completing their first year, verbal messages were communicated in a way to situate mental health staff and health centers as tools to accomplish their goals. Instead of using university language such as sign-in sheets, HIPPA, or confidentiality, concepts such as missed classes and tests, health leaves, and additional time for work were discussed. In addition, we held a workshop that presented mental health concepts in a way that was relatable to the students.

\section{CONCLUSION}

This narrative is based upon my experience after serving a four-year tenure as a student supports specialist at Cornell University. Many of my initiatives were based with various concepts of student affairs theories serving as the foundation for the design and implementation. However, this very concept design made it a challenge for the implementation of initiatives for international students. Many student development theories were created while focusing on and studying domestic Caucasian students or students of color. International student development theory literature is often criticized 
for the lack of depth, in addition to the fact that the literature on international student experiences often focus on weaknesses and not strengths of the students (Patton et al., 2016).

My inclusion of traditional student development theories to inform my practice was to treat international students like any other university student and lessen the possible marginalization of international students by treating them differently. However, my experience proved that international students are different. To provide services to them is to recognize their individual differences, attributes and characteristics. I am not sure if my efforts at Cornell saved students' lives, or helped support the college's mission. What I do know is that students knew they had an ally, a friend, and somebody that cared. And for me, that made the long days and nights worth it.

This practitioner narrative will prove to be beneficial by expanding the literature on the international student experience. While other studies have studied the international student experience at public universities (Lee \& Rice, 2007) and international student persistence and graduation (Dill \& Soo, 2004), few studies are written from a student affairs personnel perspective. It is my hope that this narrative will also provide a practitioner point of view by focusing on providing services to international students in an Ivy League university setting. Given the state of higher education finance, state appropriations, and possible cuts to federal financial aid for domestic students, many international students are identified as a pipeline of tuition revenue (Cantwell, 2015). My experience has shown me that international students do not want to be seen as revenue generating engines, but instead just as students.

In conclusion, advising and working with international students is a delicate process. While attempting to ensure that their college experience is no different than their domestic peers, university staff and faculty must still recognize cultural, religious, age, and other differences that they may have. To truly understand their lived experiences, it is vital that student affairs professionals continue to work with international students (both current and alumni) to further understand their lived experiences. This understanding may warrant seeking new training in both methodological and practical approaches to working with international students. Associations, such as the American College Personnel Association (ACPA), offer great professional development and opportunities to learn of new, innovative ways to create a more inclusive culture on their campus. My personal experience in seeking 
training from a variety of sources allowed me to assess if my college was inclusive or exclusive to international students.

\section{REFERENCES}

Cantwell, B. (2015). Are international student's cash cows? Examining the relationship between new international undergraduate enrollments and institutional revenue at public colleges and universities in the US. Journal of International Students, 5(4), 512-525

Chauncey, K., Grainger, J., \& Holcomb, P. J. (2008). Code-switching effects in bilingual word recognition: A masked priming study with event-related potentials. Brain and Language, 105(3), 161-174.

Cornell University. (2017). Towards new destinations. Retrieved from Diversity \& Inclusion: http://diversity.cornell.edu/toward-new-destinations

Cornell University International Students \& Scholars Office. (2016). 2015-2016 annual statistics. Ithaca: Cornell University.

Cornell University Office of the Registrar. (2017, May 15). Cornell University Registrar. Retrieved from Courses of Study: http://courses.cornell.edu/

Dill, D. D., \& Soo, M. (2004). Transparency and quality in higher education markets. In P. Teixeria, B. Jongloed, D. Dill, \& A. Amaral (Eds.), Markets in higher education (pp. 61-85). Dordrecht, Netherlands: Springer.

Gortner, E. M., \& Pennebaker, J. W. (2003). The archival anatomy of a disaster: Media coverage and community-wide health effects of the Texas A\&M bonfire tragedy. Journal of Social and Clinical Psychology, 22(5), 580603.

Hunt, J., \& Eisenberg, D. (2010). Mental health problems and help-seeking behavior among college students. Journal of Adolescent Health, 46(1), 310 .

Hurtado, S. (2007). Linking diversity with the educational and civic missions of higher education. The Review of Higher Education, 30(2), 185-196.

Institute of International Education. (2015). Open doors fact Sheet: China. Retrieved from http://www.iie.org/Research-and-Publications/OpenDoors/Data/Fact-Sheets-by-Country/2015\#.V3rZb67AS8Y.

Kuh, G. D. (2009). The national survey of student engagement: Conceptual and empirical foundations. New Directions for Institutional Research, 141, 520.

Ladson-Billings, G. (2012). Culture centers in higher education: Perspectives on identity, theory, and practice. Sterling, VA: Stylus Publishing.

Lee, J. J., \& Rice, C. (2007). Welcome to America? International student perceptions of discrimination. Higher education, 53(3), 381-409.

Lin, A. (2013). Classroom code-switching: Three decades of research. Applied Linguistics Review, 4(1), 195-218. 
Milroy, L., \& Muysken, P. (1995). One speaker, two languages: Cross-disciplinary perspectives on code-switching. Cambridge, UK: Cambridge University Press.

Nagda, B. A., Gurin, P., Sorensen, N., \& Zúñiga, X. (2009). Evaluating intergroup dialogue: Engaging diversity for personal and social responsibility. Diversity \& Democracy, 12(1), 4-6.

National Center for Eduation Statistics. (2016). Digest of education statistics. Retrieved from National Center for Education Statistics: https://nces.ed.gov/programs/digest/d16/tables/dt16_101.10.asp.

Parekh, B. (2000). Rethinking multiculturalism: Cultural diversity and political theory. London: Macmillan.

Patton, L. D., Guido, F. M., Quaye, S., Forney, D., \& Evans, N. J. (2016). Student development in college: Theory, research, and practice. San Francisco, CA: Jossey-Bass.

Pizzolato, J. E., Nguyen, T. L., Johnston, M. P., \& Wang, S. (2012). Understanding context: Cultural, relational, \& psychological interactions in selfauthorship development. Journal of College Student Development, 53(5), 656-679.

Schlossberg, N. K. (1989). Marginality and mattering: Key issues in building community. New Directions for Student Services, 48, 5-15.

Torres, V., Jones, S. R., \& Renn, K. A. (2009). Identity development theories in student affairs: Origins, current status, and new approaches. Journal of College Student Development, 50(6), 577-596.

Wigley, S., \& Fontenot, M. (2010). Crisis managers losing control of the message: A pilot study of the Virginia Tech shooting. Public Relations Review, 36(2), 187-189.

SILVESTER MATA is a 3rd year PhD student in the Higher Education Leadership and Policy Studies Program in the College of Education at the University of Houston. His major research interests lie in the area of student development, higher education finance and public policy. Email: slymata2@gmail.com 